\title{
Meta Analisis Pengaruh Model Pembelajaran Numbered Head Together terhadap Kemampuan Berpikir Kritis Siswa Kelas V Tematik Muatan Pembelajaran Matematika
}

\author{
Pangestu Bagas Surya Putra ${ }^{1}$, Theresia Sri Rahayu ${ }^{2}$, \\ 1, 2 Fakultas Keguruan dan Ilmu Pendidikan, Universitas Kristen Satya Wacana, \\ J1. Diponegoro No 52-60, Salatiga \\ pngstbgs@gmail.com
}

\begin{abstract}
Thematic learning is more likely to involve students mentally and physically in learning activities in class. In accordance with the nature of mathematics, one of the skills needed to solve problems at school and in everyday life in the learning process of mathematics is cooperation skills. Using the correct learning model or method will give students good and enthusiastic collaboration skills. This type of research uses Meta-analysis research, this study aims to see the effect of the NHT learning model in increasing creative thingking skills in elementary school students. The technique that has been used is the Effect Size technique analysis witht he effect size formula. From the result of this study, it shows the learning outcome model Numbered Head Together (NHT) with an average of 13.185. Judging from the result of the T-test, that the NHT learning model with a value of 66.1160 increases to 79.3010. From the result of the calculation of the hypothesis using the T-test using SPSS shows a significant valueof $(0.003<0.005)$, the SPSS test proves that T-count $>$ Ttable is 4.134 and Ttable of 3.289 shows that 4.134 $>3.289$ and the significant is $0.003<0.005$ indicates that Ho is rejected ad Ha is accepted. From this model that the increase in creative thingking skills of elementary school students.
\end{abstract}

Keywords: Numbered Head Together, Critical Thingking

\begin{abstract}
Abstrak
Pembelajaraan tematik lebih cenderung melibatkan siswa secara mental dan fisik dalam kegiatan pembelajaraan di kelas. Sesuai dengan hakikat matematika, salah satu keterampilan yang diperlukan untuk menyelesaikan masalah di sekolah dan kehidupan sehari-hari dalam proses pembelajaran matematika adalah keterampilan kerja sama. Menggunakan model atau metode pembelajaran yang benar dapat memberikan siswa ketrampilan kerjasama yang baik dan antusias. Penelitian ini bertujuan untuk mengetahui pengaruh antara model pembelajaran NHT dalam meningkatkan kemampuan berpikir kreatif pada siswa sekolah dasar. Jenis penelitian ini menggunakan penelitian meta analisis, Teknik yang telah digunakan adalah analisis teknik Effect Size dengan rumus effect size.Dari hasil penelitian ini menunjukan hasil model pembelajaran Numbered Head Together (NHT) dengan rata-rata 13.185. Dilihat dari hasil uji-T memperlihatkan bahwa model pembelajaran NHT dengan nilai sebesar 66.1160 meningkat menjadi 79.3010. Dari hasil penghitungan hipotesis penggunaan uji-T dengan menggunakan SPSS menunjukan nilai signitifikan sebesar 0,003 yang berarti lebih kecil dari 0,005 $(0,003<0,005)$ uji SPSS membuktikan Thitung>T table sebesar 4.134 dan T table sebesar 3.189 menunjukan bahwa 4.234>3.289 dan signitifikasinya 0,003<0,005 menunjukan bahwa Ho ditolak dan Ha diterima. Dari model tersebut bahwa terdapat peningkatan kemampuan berpikir kreatif siswa sekolah dasar.
\end{abstract}

Kata kunci: Numbered Head Together, Berpikir Kritis

Corresponding author: Pangestu Bagas Surya Putra

Copyright (c) 2021 Pangestu Bagas Surya Putra, Theresia Sri

Email Address: pngstbgs@gmail.com (Jl. Diponegoro No 52-60, Salatiga)

Received 16 April 2021, Accepted 19 April 2021, Published 23 April 2021

\section{PENDAHULUAN}

Sebagai metode pembelajaran akademik dan perubahan sikap, pendidikan merupakan hal yang penting.Sebagai inti dari kegiatan pendidikan sekolah, proses belajar mengajar mempunyai tujuan ganda. Tujuan utama yang diharapkan dalam proses pembelajaran adalah perubahan tingkah laku pada bidang kognitif, afektif dan psikomotorik. Pembangunan bidang pendidikan yaitu bagaimana mengembangkan kemampuan, membentuk karakter dan peradaban bangsa yang bermartabat untuk 
Meta Analisis Pengaruh Model Pembelajaran Numbered Head Together terhadap Kemampuan Berpikir Kritis Siswa Kelas V Tematik Muatan Pembelajaran Matematika, Pangestu Bagas Surya Putra, Theresia Sri Rahayu

mencerdaskan kehidupan bernegara, yang tujuannya guna mengembangkan kemampuan siswa untuk menjadi manusia yang beriman dan bertaqwa kepada Tuhan YME, berakhlak mulia, sehat, berilmu, kreatif, mandiri dan menjadi warga negara yang demokratis serta bertanggung jawab (Depdiknas UU Nomor 20, 2003)

Pembelajaran tematik yakni pembelajaraan yang melibatkan beberapa bidang penelitian untuk memberikan pengalaman dengan menghubungkan ke topik tertentu (Karli, 2012). Pembelajaraan tematik lebih cenderung melibatkan siswa secara mental dan fisik dalam kegiatan pembelajaraan di kelas. Pelaksanaan pembelajaraan tematik memadukan / mencampurkan beberapa muatan pelajaran bias mengembangkan peserta didik agar dapat berpikir holistic menurut (Setianingrum \& Wardani, 2018). Matematika merupakan ilmu deduktif abstrak di Sekolah Dasar (SD). Matematika merupakan ilmu deduktif artinya dalam proses pembelajaran matematika bukan hanya menerima induksi observasi, tetapi juga didasarkan pada pembuktian secara deduktif. Oleh karena itu, untuk membantu dalam berpikir dan menemukan jawaban dengan benar dan tepat dapat diwujudkan dengan induksi kemudian generalisasi yang benar harus dapat dibuktikan dengan cara deduktif.

Penelitian ini yang dapat ditempuh yaitu dengan metode meta analisis. Meta analisis merupakan suatu metode penelitian yang terstruktur yang disertai dengan pengumpulan data untuk menghitung kesimpulan dari beberapa hasil penelitian yang telah dilakukan sebelumnya. Peneliti mengambil beberapa penelitian yang sesuai dengan judul yang dipakai dalam penelitian ini. Metode meta analisis ini digunakan oleh peneliti untuk merangkum poin-poin penting dari hasil penelitian yang sudah pernah dilakukan.

Menurut Spencer Kagan dalam (Isjoni, 2011) NHT merupakan teknik pembelajaran yang memberikan kesempatan pada siswa untuk saling membagikan ide-ide dan pertimbangan jawaban yang paling tepat. Berdasarkan teori tersebut NHT merupakan salah satu teknik pembelajaran yang mengkondisikan siswa untuk mampu memadukan, menarik kesimpulan beragam pikiran dari hasil bertukar gagasan atau pendapat sesame teman dalam kelompoknya.

Menurut Kagan (dalam Foster, 2002:11) Numbered Head Together pembelajaran kooperatif yang merupakan stuktur sederhana terdiri dari 4 tahap digunakan untuk mereview fakta dan informasi dasar yang berfungsi untuk mengatur interaksi peserta didik. Berdasarkan berbagai pendapat ahli, peneliti menyimpulkan bahwa model pembelajaran merupakan model pembelajaran yang digambarkan dari awal sampai akhir suatu kegiatan pembelajaran yang disusun secara sistematis dan digunakan sebagai pedoman dalam merencanakan kegiatan pembelajaran untuk mencapai tujuan pembelajaran yang telah ditetapkan. Ciri utama dari model pembelajaran adalah adanya tahapan atau sintaks pembelajaran Penelitian menurut (Sari et al., 2017) penelitian ini bertujuan untuk mengetahui pengaruh model pembelajaran kooperatif tipe Numbered Head Together (NHT) berbantuan question cards terhadap kompetensi pengetahuan IPA siswa kelas V SD Negeri gugus Teuku Umar Kecamatan Denpasar Barat tahun pelajaran 2016/2017. Jenis penelitian ini adalah eksperimen semu menggunakan desain rancangan kelompok nonekuivalen. Seluruh siswa kelas V SD Negeri gugus Teuku Umar 
Kecamatan Denpasar Barat tahun ajaran 2016/2017 yang banyaknya 256 orang dijadikan populasi penelitian. Sampel ditentukan dengan teknik sampel kelompok yaitu mengacak kelas, sehingga diperoleh kelas V SD Negeri 2 Dauh Puri sebagai kelompok eksperimen dan kelas V SD Negeri 13 Dauh Puri sebagai kelompok control dengan jumlah masing-masing kelompok sebanyak 36 orang. Data hasil kompetensi pengetahuan IPA dikumpulkan dengan instrument berupa tes objektif bentuk pilihan ganda biasa berjumlah 36 butir tes yang telah divalidasi. Data kompetensi pengetahuan IPA dianalisis dengan uji t separated varian. Hasil analisis menunjukkan bahwa terdapat perbedaan yang signifikan kompetensi pengetahuan IPA kelompok eksperimen dan kelompok kontrol pada siswa kelas V SD Negeri gugus Teuku Umar Kecamatan Denpasar Barat tahun pelajaran 2016/2017. Hal tersebut dibuktikan dengan hasil thitung $=5,000>\operatorname{tabel}(\alpha=0,05,70)=2,000$. Demikian pula nilai rata-rata kompetensi pengetahuan IPA kelompok eskperimen $X=0,65>X=0,47$ rerata kompetensi pengetahuan IPA kelompok kontrol. Dengan demikian dapat disimpulkan bahwa model pembelajaran kooperatif tipe Numbered Head Together (NHT) berbantuan question cards berpengaruh terhadap kompetensi pengetahuan IPA kelas V SD Gugus IV Jendral Sudirman Kecamatan Denpasar Selatan tahun pelajaran 2016/2017.

Penelitian menurut (I Gede Budi Astrawan, 2013) tujuan dari penelitian ini ialah guna menaikkan hasil belajar siswa pada pelajaran IPA dengan penerapan model NHT di kelas V SDN 3 Tonggolobibi. Jenis penelitian ini adalah penelitian tindakan kelas yang menggunakan 2 siklus dengan desain penelitian model Kemis dan Mc Taggart. Adapun tahapan dalam penelitian ini meliputi fase perencanaan, pelaksanaan tindakan, observasi, dan refleksi. Data yang diperoleh dalam penelitian ini meliputi hasil observasi aktivitas guru, dan lembar observasi aktivitas siswa. Subjek penelitian ini adalah siswa kelas V SDN 3 Tonggolobibi yang berjumlah 28 orang yang terdiri dari 16 orang laki - laki dan 12 orang perempuan. Tes hasil tindakan siklus I diperoleh persentase kentuntasan klasikal sebesar 53,57\%, persentase daya serap klasikal 55,71\%. Pada siklus II hasil tes tindakan meningkat. Siklus II diperoleh persentase ketuntasan klasikal sebesar $85,71 \%$, persentase daya serap klasikal sebesar $76.07 \%$. Berdasarkan hasil tindakan siklus I dan II dapat disimpulkan bahwa dengan penerapan model kooperatif Tipe NHT dapat meningkatkan hasil belajar siswa di kelas V SDN 3Tonggolobibi.

Berdasarkan membaca refrensi-refrensi tentang model pembelajaran kooperatif tipe NHT, dimana model tersebut menguji kemampuan berpikir kreatif pada mata pelajaran tematik siswa kelas $\mathrm{V}$ SD dan untuk mencapai keefektivitasan pada pembelajaran tematik terpadu. Dari paparan tersebut dengan demikian tujuan penelitian ini adalah untuk mengetahui pengaruh model pembelajaran NHT terhadap kemampuan berpikir kreatif pada pembelajaran tematik siswa kelas V SD.

\section{METODE}

Metode yang digunakan dalam penelitian ini yaitu meta-analisis. Meta-analisis yaitu penelitian yang dilakukan dengan cara merangkum, mereview dan menganalisis data penelitian dari beberapa hasil 
Meta Analisis Pengaruh Model Pembelajaran Numbered Head Together terhadap Kemampuan Berpikir Kritis Siswa Kelas V Tematik Muatan Pembelajaran Matematika, Pangestu Bagas Surya Putra, Theresia Sri Rahayu

penelitian sebelumnya, kemudian memperoleh data yang valid. Menurut Rahmat Alyakin Dachi (2017: 335) meta analisis ialah proses penelitian dapat dilakukan dengan kegiatan merangkum, mereview, dan menganalisis data penelitian yang sudah dilakukan oleh penelitilain. Menurut Punaji Setyosari(2016 : 51) mendefinisikan meta analisis sebagai suatu penelitian yang dilakukan seseorang dengan cara menyatukan dan menganalisis hasil dari penelitian yang sama yang kemudian diuji untuk memperoleh hasil dari penelitian telah dianalisis sesuai dengan unsur yang ada dalam penelitian.

\section{HASIL DAN DISKUSI}

Penelitian ini dilakukan untuk mengetahui apakah model pembelajaran Numbered Head Together mempengaruhi terhadap kemampuan berpikir kreatif siswa kelas V SD. Berdasarkan hasil penelusuran sesuai dengan temuan yang sudah dirinci oleh peneliti dengan menemukan 10 jurnal yang relevan. Berdasarkan pengumpulan artikel yang diperoleh dari jurnal dengan cara merangkum atau komparasi dari model pembelajaran Numbered Head Together (NHT) Berikut tabel hasil komparasi model pembelajaran $N H T$ :

Tabel 1. Hasil Analisis Pendekatan Numbered Head Together Terhadap Kemampuan Berpikir Kritis Siswa

\begin{tabular}{|c|c|c|c|c|}
\hline \multirow{2}{*}{ No } & \multirow{2}{*}{ Kode Jurnal } & \multicolumn{3}{|c|}{ Peningkatan Kemampuan Berpikir } \\
\cline { 3 - 5 } & & Presentase (\%) \\
\cline { 3 - 5 } & & Pre-test & Post-test & Peningkatan \\
\hline 1 & $\mathrm{X} 1$ & 68.37 & 79.69 & 11.32 \\
\hline 2 & $\mathrm{X} 2$ & 74 & 81 & 7 \\
\hline 3 & $\mathrm{X} 3$ & 76 & 90 & 14 \\
\hline 4 & $\mathrm{X} 4$ & 73 & 84,60 & 0.04 \\
\hline 5 & $\mathrm{X} 5$ & 86.20 & 89.65 & 8 \\
\hline 6 & $\mathrm{X} 6$ & 58.35 & 85.45 & 27.1 \\
\hline 7 & $\mathrm{X} 7$ & 56.25 & 87.5 & 31.25 \\
\hline 8 & $\mathrm{X} 8$ & 68.43 & 78.12 & 9.69 \\
\hline 9 & $\mathrm{X} 9$ & 66.116 & 79.301 & 13.185 \\
\hline 10 & $\mathrm{X} 10$ & & & \\
\hline \multicolumn{7}{|c|}{ Rata-Rata } & & & \\
\hline
\end{tabular}

Berdasarkan tabel 1 diatas, dapat diketahui bahwa model pembelajaran Numbered Head Togeteher dapat meningkatkan berpikir kreatif pada pembelajaran tematik siswa Sekolah Dasar menggunakan model pembelajaran. Presentase rata-rata (mean) kenaikan berpikir kreatif pada pembelajaran tematik menggunakan model pembelajaran Numbered Head Together dari skor terendah sebesar $0,04 \%$ dan skor tertinggi sebesar $31,25 \%$ dengan rata-rata sebesar $13,18 \%$. Presentase mean berpikir kreatif pembelajaran tematik skor pretest menggunakan model pembelajaran Numbered Head Together sebesar 66,11\%. Presentase mean berpikir kreatif pembelajaran tematik skor posttest menggunakan model pembelajaran Numbered Head Together sebesar 79,30\%. Presentase mean sebelum dan sesudah menggunakan model pembejaran Numbered Head Together mengalami peningkatan sebesar13,18\%. 


\section{Uji T (paired-sampleT Test)}

Tabel 2. Paired Sample Statistic (Statistik Sampel Berpasangan)

Paired Samples Statistics

\begin{tabular}{|rl|r|r|r|c|}
\hline & Mean & N & Std. Deviation & $\begin{array}{c}\text { Std. Error } \\
\text { Mean }\end{array}$ \\
\hline \multirow{2}{*}{ Pair 1 } & PRE & 66.1160 & 10 & 12.09631 & 3.82519 \\
& POST & 79.3010 & 10 & 11.16034 & 3.52921 \\
\hline
\end{tabular}

Berdasarkan hasil output Paired Samples T Test menunjukan bahwa Model Numbered Head Together dapat meningkatkan kemampuan berpikir kritis siswa dengan nilai rata-rata 66.1160 menjadi 79.3010 .

Tabel 3. Paired Samples Correlations (Kolerasi Sampel Berpasangan)

\section{Paired Samples Correlations}

\begin{tabular}{|lr|r|r|r|}
\hline & \multicolumn{1}{|c|}{$\mathrm{N}$} & Correlation & \multicolumn{1}{c|}{ Sig. } \\
\hline Pair 1 & PRE \& POST & & .627 & .053 \\
\hline
\end{tabular}

Table 3 menunjukan adanya relasi antara berpikir kritis rata-rata sebelum dan sesudah menggunakan model pembelajaran Numbered Head Together sebesar 627. $\mathrm{H} 0=$ terdapat perbedaan berfikir kritis Matematika siswa sebelum menggunakan metode Numbered Head Together dan $\mathrm{H} 1$ = menunjukan perbedaan yang signifikan berfikir kritis Matematika peserta didik sebelum menggunakan metode Numbereh Head Together.

Tabel 4 Paired Samples Test

Paired Samples Test

\begin{tabular}{|c|c|c|c|c|c|c|c|c|}
\hline & \multicolumn{5}{|c|}{$\begin{array}{c}\text { Paired } \\
\text { Differences }\end{array}$} & \multirow[t]{3}{*}{$\mathrm{t}$} & \multirow[t]{3}{*}{ df } & \multirow[t]{3}{*}{$\begin{array}{l}\text { Sig. (2- } \\
\text { Tailed ) } \\
\end{array}$} \\
\hline & \multirow[t]{2}{*}{ Mean } & \multirow{2}{*}{\begin{tabular}{c|} 
Std. \\
Deviation
\end{tabular}} & \multirow[t]{2}{*}{$\begin{array}{l}\text { Std. Error } \\
\text { Mean }\end{array}$} & \multicolumn{2}{|c|}{$\begin{array}{c}95 \% \text { Confidence Interval of } \\
\text { the Difference }\end{array}$} & & & \\
\hline & & & & Lower & Upper & & & \\
\hline Pair 1 Pre - Post & 13.18500 & 10.08559 & 3.18934 & 20.39980 & 5.97020 & 4.134 & 9 & .003 \\
\hline
\end{tabular}

Tabel 4 menunjukkan nilai Sig. $(2$-tailed $)(0,000)<\alpha(0,05)$ dan thitung $=4.134<$ ttabel $=2.306$ sehingga Ho ditolak. Jadi, dapat ditarik kesimpulan bahwa terdapat sebuah perbedaan kemampuan berpikir kritis muatan pelajaran Matematika siswa sebelum dan sesudah menggunakan pendekatan Numbered Head Together. Berdasarkan hasil analisis penelitian dapat dilihat bahwa kemampuan berpikir kritis Matematika siswa dari masing-masing penelitian dapat meningkatkan kemampuan 
Meta Analisis Pengaruh Model Pembelajaran Numbered Head Together terhadap Kemampuan Berpikir Kritis Siswa Kelas V Tematik Muatan Pembelajaran Matematika, Pangestu Bagas Surya Putra, Theresia Sri Rahayu

berpikir kritis Matematika dengan menggunakan pendekatan Numbered HeadTogether.

\section{Effect Size}

Effect Size ialah satuan standar yakni dapat dibandingkan antar beberapa skala yang berbeda beda. Effect Size yang dapat digunakan dalam penelitian ini adalah Cohen's d, dapat diartikan bahwa semakin besar nilainya maka semakin besar efek dari model Numbered Head Together terhadap pembelajaran Matematika SD. Berikut ini interpretasi Effect Size sebagai berikut

Tabel 5. Interpretasi Effect Size Cohen's d

\begin{tabular}{|c|c|}
\hline Effect Size & Interpretasi \\
\hline $0<\mathrm{d}<0,2$ & Kecil \\
\hline $0,2<\mathrm{d} \leq 0,5$ & Sedang \\
\hline $0,5<\mathrm{d} \leq 0,8$ & Besar \\
\hline $\mathrm{d}>0,8$ & Sangat Besar \\
\hline
\end{tabular}

Berikut adalah hasil analisis Effect Size yang dilakukan untuk melihat besaran efek model Numbered Head Together.

Tabel 6. Hasil uji Effect Size Menggunakan Uji T

Paired Samples Test

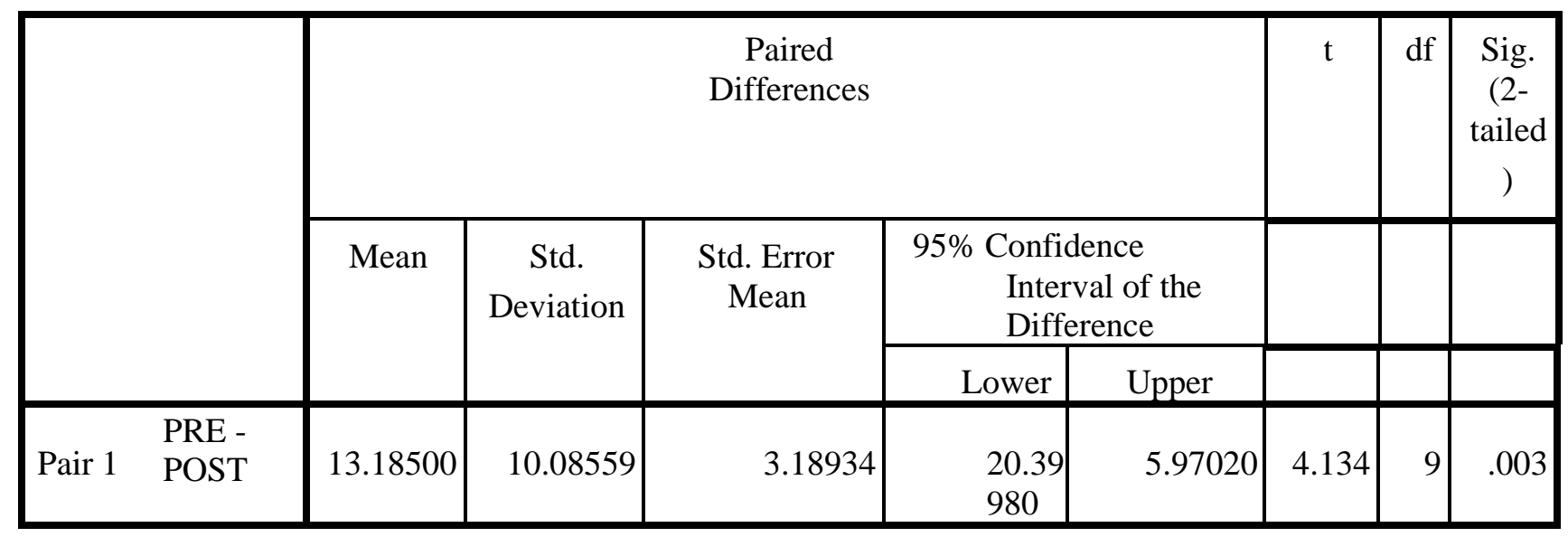

Rumus Pengukuran Efek Size Paired Samples Test:

$\mathrm{d}=$ Mean $/$ Std.Deviation

$=13.18 / 10.08=1.318($ Kategori Sangat Besar) Keterangan: d: Efek Size

Mean: Rata-Rata Dari Hasil Pengujian Paired Samples Test Std.Deviation: Hasil Pengujian Paired Samples Test.

Berdasarkan tabel diatas dapat disimpulkan bahwa hasil uji Effect Size dengan menggunakan Uji-T dapat dilihat dari hasil Paired Sample Test terdapat hasil yang tertera pada kolom Mean sebesar13.18 dan Standart Deviation sebesar 10.08 dan memiliki nilai sig 0,003. Maka besaran Effect Size yang diperoleh adalah sebesar 1,318 dan dapat dilihat dari table interpretasi Cohen's d bahwa model Pembelajaran Numbered Head Together berpengaruh besar pada pembelajaran matematika SD.

Effect Size Penggunaan NHT pada Pembelajaran Matematika SD dari 10 artikel yang dirangkum yang terdapat nilai effect size hanya 1 artikel selebihnya 9 artikel dilakukan perhitungan effect size 
kembali. Perhitungan harga effect size menghasilkan harga effect size rata-rata total sebesar 13.18 Dimana arti nilai tersebut bahwa penerapan NHT efektif digunakan dalam pembelajaran.

\section{KESIMPULAN}

Perbedaan terhilat sangat berbeda-beda, ada peningkatannya dengan besar dan ada juga peningkatannya cukup. Hal ini dapat dipengaruhi oleh beberapa hal, baik dari faktor internal maupun eksternal. Beberapa factor internal berasal dari dalam diri peserta didik seperti kemampuan, minat, bakat dan kondisi kesehatan tubuh. Faktor eksternal berasal dari luar diri peserta didik seperti keluarga, sekolah dan lingkungan masyarakat. Penelitian yang dilakukan dari daerah yang berbeda-beda juga berpengaruh terhadap hasil penelitian yang diperoleh. tingkat kemampuan siswa di setiap daerah juga berbeda sehingga juga berpengaruh terhadap kemampuan berpikir kritis siswa.

Berdasarkan hasil analisis pendekatan Numbered Head Together dapat disimpulkan bahwa pendekatan tersebut mampu meningkatkan kemampuan berpikir kritis peserta didik mulai yang terendah 0.04 hingga yang tertinggi 31,25 dengan rata-rata sebesar 13.185. Saran bagi peneliti selanjutnya supaya dapat menggunakan artikel atau sumber lainnya yang lebih banyak dan relevan dari penelitian sebelumnya. Diharapkan waktu penelitian selanjutnya peneliti mampu lebih ketat dalam menyeleksi dan memilih hasil penelitian yang akan digunakan dalam penelitian meta analisis, dan penggunaan cara statistic harus diperhatikan hasil dari meta analisis yang diperoleh lebih tepat serta akurat.

\section{UCAPAN TERIMA KASIH}

Peneliti sekaligus penulis mengucapkan terima kasih kepada semua pihak yang membantu proses penelitian ini. Puji syukur kepada Tuhan Yang Maha Esa yang telah memberikan kemudahan dalam jalannya penelitian ini. Dan terima kasih juga peneliti ucapkan untuk dosen pembimbing, orang tua, serta teman-teman yang selalu memberikan support selama penelitian ini berlangsung.

\section{REFERENSI}

Anidawati, A. (2018). Penerapan Model Pembelajaran Koperatif Tipe Nht Untuk Meningkatkan Hasil Belajar Pkn Siswa Kelas V Sd Negeri 1 Bathin Solapan Kecamatan Bathin Solapan. Primary: Jurnal Pendidikan Guru Sekolah Dasar, 7(2), 321. https://doi.org/10.33578/jpfkip.v7i2.6277 Depdiknas UU Nomor 20. (2003). UNDANG-UNDANG REPUBLIK INDONESIA NOMOR 20 TAHUN 2003 TENTANG SISTEM PENDIDIKAN NASIONAL. 05(02), 51.

Elendiana, M., \& Prasetyo, T. (2021). Efektivitas Model Pembelajaran NHT dan Model Pembelajaran STAD Terhadap Kemampuan Berpikir Kreatif Pada Pembelajaran Tematik. 7(1), 228-237. https://doi.org/10.31949/educatio.v7i1.932

Hartina Kusuma Dewi, Amir, S. (2014). 1 PENINGKATAN HASIL BELAJAR IPS MELALUI MODEL PEMBELAJARAN KOOPERATIF TIPE NUMBERED HEADS TOGETHER (NHT) 
Meta Analisis Pengaruh Model Pembelajaran Numbered Head Together terhadap Kemampuan Berpikir Kritis Siswa Kelas V Tematik Muatan Pembelajaran Matematika, Pangestu Bagas Surya Putra, Theresia Sri Rahayu

Hartina Kusuma Dewi 1), Amir 2) ,Sukarno 3). Vol 2, No(2337-8786), 1-6.

I Gede Budi Astrawan. (2013). Penerapan Model Kooperatif Tipe NHT Dalam Meningkatkan Hasil Belajar Siswa Pada Pelajaran IPA Di Kelas SDn 3 Tonggolobibi. Jurnal Kreatif Tadulako Online, Vol. 3 No.(ISSN 2354-614X), 68-70.

Isjoni. (2011). Pembelajaran Kooperatif Meningkatkan Kecerdasan Komunikasi Antar Peserta Didik. Pustaka Pelajar.

Karli. (2012). Pembelajaraan Tematik untuk Meningkatkan Jiwa Kewirausahaan. Jurnal Pendidikan Penabur, 52-63.

Sari, N. K. T. N., Suniasih, N. W., \& Wiarta, I. W. (2017). Pengaruh Model Pembelajaran Kooperatif Tipe Nht Berbantuan Question Cards Terhadap Kompetensi Pengetahuan Ipa. MIMBAR PGSD Undiksha, 5(2).

Setianingrum, S., \& Wardani, N. S. (2018). Upaya Peningkatan Hasil Belajar Tematik Melalui Discovery Learning Siswa Kelas 1 Sekolah Dasar. Jurnal Pendidikan Dasar, 9(2), 149-158. 